\title{
New Small Mammals From the Hasnot-Tatrot Area of the Potwar Plateau, Northern Pakistan
}

\section{Citation}

Khan, M. Akbar, Lawrence J. Flynn. 2017. New Small Mammals From the Hasnot-Tatrot Area of the Potwar Plateau, Northern Pakistan. Paläontologische Zeitschrift 91, no. 4: 589-599.

\section{Published Version}

10.1007/s12542-017-0375-3

\section{Permanent link}

http://nrs.harvard.edu/urn-3:HUL.InstRepos:42656566

\section{Terms of Use}

This article was downloaded from Harvard University's DASH repository, and is made available under the terms and conditions applicable to Open Access Policy Articles, as set forth at http:// nrs.harvard.edu/urn-3:HUL.InstRepos:dash.current.terms-of-use\#OAP

\section{Share Your Story}

The Harvard community has made this article openly available.

Please share how this access benefits you. Submit a story.

Accessibility 


\section{NEW SMALL MAMMALS FROM THE HASNOT-TATROT AREA OF THE POTWAR PLATEAU, NORTHERN PAKISTAN} \\ Muhammad Akbar Khan ${ }^{1}$ and Lawrence J. Flynn² \\ 1. Department of Zoology, University of the Punjab, Lahore, Punjab, Pakistan (38000) \\ 2. Department of Human Evolutionary Biology, Harvard University, Cambridge, MA 02138, USA
}

Key Words Rhizomyinae, Hystrix, Alilepus, Siwalik, Pakistan, late Miocene, Pliocene

\begin{abstract}
New rodent and lagomorph fossils from the Hasnot-Tatrot area of northern Pakistan are presented here to complement knowledge of stratigraphic ranges and morphology of key late Neogene Siwalik taxa. Most of the material is from two sites near the village of Bhandar in strata of the late Miocene age Dhok Pathan Formation; one specimen comes from the Pliocene Tatrot beds. We apply previously established magnetostratigraphy to date the fossils, the Bhandar sites dating to 6.6 to $6.7 \mathrm{Ma}$. In describing the fossils, we emphasize new morphological information represented by the material. As surface finds, these fossils represent relatively large body size species, three bamboo rat relatives, a porcupine, and a rabbit. The bamboo rats (Rhizomyinae) are an endemic group, and both the porcupine (Hystrix) and the rabbit (Alilepus) represent late Miocene immigrants into the Indian subcontinent.
\end{abstract}




\section{Introduction}

One of the classical areas in the Siwalik Group deposits to produce late Miocene and Pliocene vertebrate fossils over many years is the Hasnot-Tatrot area of northern Pakistan, particularly the terrestrial deposits near the village of Bhandar. Barnum Brown (Brown et al. 1924) and G.E. Lewis (1937) provided provenance for their collections from the area early last century. The YaleGeological Survey of Pakistan (Y-GSP) project developed refined geographic and biostratigraphic controls for new fossil finds in the region, especially during the 1990s (Barry et al. 2002). In recent years, field teams from the University of the Punjab, Lahore, have continued work in the area, collecting important new fossils and documenting locality provenance.

Among the fossil materials recovered by University of the Punjab teams are mammalian groups not well represented among surface finds. Here we report on small mammal fossils from the area, which are significant from two aspects. They increase the number of biostratigraphic records with good provenance for taxa that were poorly documented previously, and they provide new morphological data for incompletely known species. The new fossils come, primarily, from two localities very near the village of Bhandar (Fig. 1). One other specimen comes from the well-known Pliocene Tatrot horizon, a fossil-rich surface developed on a sandstone dip slope that crops out prominently at Tatrot Village, $10 \mathrm{~km}$. to the northeast.

The Bhandar fossil localities are at the same stratigraphic level in exposures immediately north of the village Bhandar. These sites $\mathrm{H} 16$ and $\mathrm{H} 18$ lie just below a distinctive sand layer in the upper part of the Dhok Pathan Formation that the Y-GSP project referred to as the Pillar Sandstone. The Pillar Sandstone can be traced laterally for several kilometers and is associated with fossils above and below it. The new sites are subjacent to the sandstone and occur in the vicinity of fossil 
localities worked by Lewis (his site L97) and by Brown (his site B135). Y-GSP teams worked in this area and documented another locality (Y453) about $1 \mathrm{~km}$ to the north. Y453 lies in the Y-GSP magnetostratigraphic section at the top of Chron C3An.2n, at 6.5 Ma. The older sites H16 and H18 fall lower in the magnetozone, where they would date to between 6.6 and $6.7 \mathrm{Ma}$. Several of the fossils are mandibles representing bamboo rats (Rhizomyinae), and other specimens represent a porcupine and a rabbit, both late Miocene immigrants to northern Pakistan.

Methods. Eight new University of the Punjab fossils, all surface finds, are described and discussed here in the following systematic account. They are designated with the acronym PUPC, and are housed in the permanent collections of the Department of Zoology of the university. Specimens were measured in millimeters $(\mathrm{mm})$ by a Nikon microscope fitted with a reticle, and large dimensions were taken by calipers. Specimens were photographed initially with a Canon EOS 350D 8.0 megapixel DSLR camera, lens $18-55 \mathrm{~mm}$; close-ups were also made with a Dino-Lite digital microscope.

Abbreviations. L, W, for length and width of teeth; A-P for the antero-posterior dimension of the incisor (right angle to its width). Standard tooth terminology is used: upper case letters plus a numeral for upper teeth (e.g., M3 for the upper third molar) and lower case plus numeral for lower teeth (e.g., p4 for lower fourth premolar). " $\mathrm{Y}$ " is as prefix for Y-GSP localities.

\section{Systematic palaeontology}

Order Rodentia Bowdich, 1821

Family Spalacidae Gray, 1821

Subfamily Rhizomyinae Winge, 1887 
Genus Miorhizomys Flynn, 2009

Type species. M. nagrii (Hinton, 1933), from "Nagri zone" near Haritalyangar, northern India. Diagnosis. Member of Tribe Rhizomyini with moderately deep dentary and a masseteric crest lacking a strong anterior extension, lower crest not inflated; lower incisor with flattened enamel and no median ridge; molars relatively small, of moderate crown height, with unilateral hypsodonty; M1 rounded anteriorly, without anterolingual flexus; $\mathrm{m} 2$ with three roots and strong mesolophid; longitudinal connection (mure) on $\mathrm{m} 2$ and $\mathrm{m} 3$ with small posterolingual enamel lake and often a deep buccal reentrant; incomplete closure of ventral slit of the infraorbital foramen; pronounced fossorial adaptations, low elevation of the skull.

Discussion. Miorhizomys is related to living bamboo rats, and therefore exhibits the fossorial characteristics of crown group Tribe Rhizomyini, namely large size, robust jaws and skulls, digging adaptations of the postcrania, chisel-like incisors, and deep dentaries. The lower incisor is particularly derived (Fig. 2). Unlike the round incisor with a single median ridge in the rhizomyines of Tribe Tachyoryctini, the chisel-like lower incisor of Miorhizomys and later Rhizomyini is deep anteroposteriorly, shows flattening of the enamel, and is smooth, without a median ridge.

Miorhizomys choristos (Flynn, 1982)

(Fig. 3a-c)

Type specimen. YGSP 4053, partial skull and skeleton from Y172, Dhok Pathan Formation near Mahluwala, Khaur area, Potwar Plateau, 8.3 Ma.

Studied material. PUPC 00/37, partial left dentary with incisor and m2-3; locality H16, 6.6 to 6.7 Ma. 
Description. The left dentary represents a large bamboo rat, and as a member of the Rhizomyini clade, it shows burrowing features. It is robust and deep, and despite loss of bone along the ventral border of the incisor, jaw depth below $\mathrm{m} 2$ is $14.9 \mathrm{~mm}$. The dentary is broken $6 \mathrm{~mm}$ anterior to the alveolus of $\mathrm{m} 1$ and $8.5 \mathrm{~mm}$ posterior to $\mathrm{m} 3$. The masseteric crest is prominent, but the lower portion is not greatly inflated, lacks an anterior extension, and intersects the upper portion as a rounded junction below $\mathrm{m} 1$, above the midline of the dentary. Anterior to this junction, at about the midline, is the mental foramen. The first lower molar is absent, but would have been small, relative to $\mathrm{m} 2-3$ as in the type specimen of $M$. choristos. The alveolus for $\mathrm{m} 1$ narrows anteriorly, given the small, round anterior root and the broad, oblique posterior root. The large posterior root of the last molar makes the alveolus of $\mathrm{m} 3$ extend beyond its posterior wall. Although $\mathrm{m} 1$ is missing, the alveolar length of the molar row $(13.6 \mathrm{~mm}$, Table 1 ) would exceed somewhat the actual length of m1-3.

Molars are lophodont and slightly higher crowned buccally than lingually. The protoconid of $\mathrm{m} 2$ is the largest cusp, and the metaconid is the highest component of the occlusal surface. The $\mathrm{m} 2$ is tetralophodont, with the metaconid and entoconid being large, transverse cusps incorporated into the metalophid and hypolophid, respectively. The connections of the metaconid to the protoconid and of the entoconid to the hypoconid are narrow, and these cusps would be isolated in early wear. Similarly, the central connection between protoconid and hypoconid is weak at this stage of wear. The posterolophid continues lingually from the hypoconid, nearly to the margin of the tooth, but the mesolophid is a short extension of the protoconid, terminating lingual to the midline of $\mathrm{m} 2$. Dimensions of $\mathrm{m} 2$ are $4.35 \mathrm{~mm}$ long by $5.05 \mathrm{~mm}$ wide. 
The third molar $(5.8 \times 4.4 \mathrm{~mm})$ is longer but narrower than $\mathrm{m} 2$, and less worn (a rhizomyine characteristic is a strong wear gradient, increasing anteriorly). Its protoconid and metaconid are smaller but similar to those of $\mathrm{m} 2$; the entoconid is much smaller than on $\mathrm{m} 2$. The mesolophid is quite short and abuts tightly the entoconid, with which it will unite after further wear. The major buccal reentrant is deep, extending directly to the entoconid, such that the hypolophid is reduced to a thin posteriorly-directed connection that joins the posterolophid slightly lingual to the midline of $\mathrm{m} 3$. The posterolophid is less broad than that of $\mathrm{m} 2$. As a consequence of the transverse reduction of the tooth, the posterior lake of $\mathrm{m} 3$ is small and positioned lingually. The incisor is stout ( $4.3 \mathrm{~mm}$ transverse, $6.1 \mathrm{~mm}$ antero-posterior), triangular in cross section, with flattened anterior surface. The anteromedial corner is slightly more acute than a right angle; the anterolateral corner is rounded, with the enamel wrapping onto about $30 \%$ of the lateral side of the incisor. The enamel bears fine rugosities, but is otherwise smooth.

\section{Genus Rhizomyides Bohlin, 1946}

Type species. R. sivalensis Bohlin, 1946, from late Miocene Haritalyangar, northern India. Diagnosis (emended). Medium size to large tachyoryctine with moderate hypsodonty, high crowned in early wear; lower masseteric crest inclined, extending anteriorly beyond upper masseteric crest; lower molar mesolophids well developed, large posterior enamel lake on m3; dentary not deepened and incisor has rounded enamel.

Discussion. Rhizomyides is a long-ranging (temporally) tachyoryctine, and not a member of the crown bamboo rats. The genus does not display the array of strongly fossorial traits evident in Miorhizomys (Flynn, 2009). For example (Fig. 3b, e), the dentary is much shallower than in the 
rhizomyine Miorhizomys. Its masseteric crest differs greatly from that of Miorhizomys: the lower part is inflated and extends anteriorly beyond the upper crest. The genus also retains primitive incisor morphology (Fig. 2): smaller incisor with rounded enamel bearing a longitudinal ridge.

Rhizomyides sivalensis (Lydekker, 1884)

(Fig. 3d-f; Fig. 4a-f)

Studied material. PUPC 09/30, right dentary fragment with incisor, m2-3 from H16. From H18, PUPC 09/31 and 09/32, right and left halves of mandible of one individual with all teeth. All specimens 6.6 to $6.7 \mathrm{Ma}$.

Description. This large member of the genus has a dentary that is shallow relative to that of Rhizomyini (Fig. 3e, depth below m2 = $9.9 \mathrm{~mm}$ on PUPC 09/30; $9.8 \mathrm{~mm}$ on PUPC 09/32). Although incomplete, PUPC 09/30 preserves much of the dentary morphology; its $31.4 \mathrm{~mm}$ length includes a high condyle and a strong coronoid process (both broken). Alveolar length of the molar row is $11.6 \mathrm{~mm}$. On all specimens, the masseteric crest is prominent, the lower portion particularly inflated and inclined. It joins the upper part of the crest below the posterior root of $\mathrm{m} 1$, and continues anteriorly with an extension below the anterior root of $\mathrm{m} 1$, at the midlevel of the dentary. Anterior to $\mathrm{m} 1$ at the midlevel of the jaw is the mental foramen.

Molars are slightly higher crowned buccally than lingually. Wear transforms the lophodont pattern into a flattened occlusal surface, yet it should be noted that, for both Rhizomyides and Miorhizomys, the surface of the molar row is not a plane. This is most evident for the mandible PUPC 09/31-32. The wear surface is a slightly concave, helical groove (due to wear by the upper dentition), deep at the lingual side of $m 3$, running anteriorly and slightly diagonally across $m 2$ toward its anterobuccal side, and continuing on the buccal side of $\mathrm{m} 1$. The result is greater wear 
on the buccal sides of, especially, $\mathrm{m} 2$ and $\mathrm{m} 1$. The molar row is preserved in PUPC 09/31 and 09/32, with length of 13.7 and $13.2 \mathrm{~mm}$, respectively.

Unworn lower molars are mesodont and inclined anteriorly. The first molar is narrowest, but elongated. The large hypoconid continues lingually with a sweeping posterolophid.It has a narrow connection to the posterior arm of the protoconid near the midline of the tooth. The posterior arm of the protoconid continues lingually and bifurcates as an entoconid and a short, narrow mesolophid, both lingual in position. The entoconid is large, with accessory spurs, and upon wear joins the posterolophid lingually. Opposite the protoconid is a broad lingual reentrant whose anterior wall is the metaconid. The metaconid joins the protoconid not directly, but at the base of its anterior arm, which continues as the anterolophid. The anterolophid is a D-shaped anterior complex that joins the protoconid buccal to the midline of the tooth and the metaconid at the lingual side. There is a broad transverse sinus between hypoconid and protoconid, and a smaller sinus between protoconid and anterior complex.

The $\mathrm{m} 2$ and $\mathrm{m} 3$ are represented by specimens in early and late wear. The shape of the tooth causes apparent change in the dimensions of the occlusal surface: the longer than wide tooth in early wear seems to become wider than long in late wear. This accounts for the considerable variation in measurements of Table 1. Also, the entire molar row (m1-m3) wears such that old individuals appear to have short tooth rows. The dominant features of $\mathrm{m} 2$ are a triangular protoconid and hypoconid with deep, posteriorly-directed buccal reentrant, and four transverse crests, the metalophid, mesolophid, hypolophid, and posterolophid. Because the buccal reentrant or sinus is deep, crossing half of the tooth, the hypolophid and mesolophid opposite the sinus are short. The metalophid and hypolophid widen at the lingual wall, representing an 
expanded metaconid and entoconid, respectively. The mesolophid between is narrow and nearly reaches the lingual wall (later wear unites the mesolophid with the wall). The sweeping posterolophid is the distal wall of the tooth. These structures yield three lingual enamel lakes for $\mathrm{m} 2$, the smallest between mesolophid and hypolophid. An interesting variation is observed in slightly worn m2 (not m3) of PUPC 09/31 and 09/32: the straight anterior wall of the anterolophid includes a short buccal arm that makes an ephemeral notch in the occlusal trace of the enamel. This feature with other molar and incisor morphology is inherited from Kanisamyslike structures of earlier Rhizomyinae.

The last lower molar is narrower than $\mathrm{m} 2$ (see Table 1 ), but its base expands distally so that a length measurement including the base of the tooth is greater than at the occlusal surface. Its anterior width is less than that of $m 2$, and $m 3$ narrows posteriorly. The structure of the metalophid is much like that of $\mathrm{m} 2$, but the mesolophid is somewhat shorter. In lightly worn PUPC 09/31 and 09/32, the lingual end of the metalophid preserves a tiny enamel lake that recalls the free lingual end of the anterolophid of early Rhizomyinae. The narrow posterior end of m3 has its hypoconid slightly displaced lingually, and its entoconid greatly displaced buccally and reduced, relative to $m 2$. The posterolophid is greatly shortened relative to that of $m 2$, and the posterior enamel lake is correspondingly small. In slightly worn PUPC 09/31 and 09/32 the posterior lake is even smaller than the middle lake between hypolophid and mesolophid, but those proportions reverse with wear. In later wear, the shallower middle lake disappears, but the posterior lake persists, and is relatively bigger than that of the m3 of Miorhizomys. Intraindividual variation is evident in comparing left and right m3; PUPC 90/32 has a third molar that 
is more vertically disposed, with a less posteriorly projecting distal extremity - thus its length measurement is less than that of PUPC 90/31.

The lower incisor of Rhizomyides contrasts greatly with that of Miorhizomys. The incisor has a rounded enamel face, sharply rounded medially and broadly rounded laterally, with enamel wrapping half way around its lateral side. There is a strong, persistent ridge of raised enamel running medial to the midline of the shaft. This contrasts sharply with the smooth, flat enamel of the stout incisor of Miorhizomys (Fig. 2). Measurements (Table 1) vary depending on incisor maturity (individual age, or where measured in the jaw).

Genus Protachyoryctes Hinton, 1933

Type species. P. tatroti Hinton, 1933, form late Miocene deposits below Tatrot Village, northern Pakistan, only known species.

Diagnosis (emended). Medium size and hypsodont; lower masseteric crest nearly horizontal, not strongly inclined; lower molars with deep buccal reentrants, reduced mesolophids, and strong posterolophids; lower incisor relatively small, with strongly rounded enamel.

Discussion. This monotypic genus is known only from the late Miocene of the Potwar Plateau, northern Pakistan. A member of Tachyoryctini, it is not strongly fossorial, but rather has molars of crown height great enough to be considered hypsodont. Its masseteric crest is similar to, but not as inclined as in Rhizomyides, and its incisor is relatively smaller and strongly rounded.

Protachyoryctes tatroti Hinton, 1933

(Fig. 4g, h) 
Studied material. PUPC 90/34, damaged right dentary with broken incisor and m2-3, from H18, 6.6 to $6.7 \mathrm{Ma}$ in age.

Description: Alveolar length of tooth row, on poorly preserved PUPC 90/34 about $10.4 \mathrm{~mm}$; mandibular depth below $\mathrm{m} 2$ is $7.7 \mathrm{~mm}$. Tooth dimensions (Table 1 ) are less than corresponding measurements for Rhizomyides sivalensis. The bone surface is weathered, but the lower masseteric crest is nearly horizontal, not inclined. Molars are still high crowned despite significant wear. The $\mathrm{m} 2$ is partly missing, but a thin mesolophid is evident and the middle enamel lake is small. Buccal sinuses of $\mathrm{m} 2$ and $\mathrm{m} 3$ are deep. The posterior lake of $\mathrm{m} 3$ is large. The incisor is strongly rounded in cross section, the enamel bearing a single ridge. Discussion. The damaged PUPC 90/34 resembles Rhizomyides specimens, but preserves few distinctive features. The partially-preserved heavy masseteric crest is nearly horizontal, the relatively small incisor is rounded with a ridge, and the molars in their worn state show complete transverse lophs and a large posterior lake. Tooth dimensions (Table 1) are too small for Rhizomyides sivalensis, but consistent with Protachyoryctes tatroti, previously known from nearby sites in the Dhok Pathan Formation. This specimen is younger than previously known fossils, which date to 7.8 to $7.1 \mathrm{Ma}$.

Family Hystricidae Fischer, 1817

Genus Hystrix Linnaeus, 1758

Type species. H. cristata Linnaeus, 1758, extant in Europe.

Hystrix sp. (Fig. 5c-e) 
Studied material. PUPC 15/444, upper left incisor tip from H18, 6.6 to 6.7 Ma; PUPC 09/35, right M3 from Tatrot Village, 3.4 Ma (estimate in Barry et al. 2002).

Description. The strongly curved incisor represents an upper tooth, with tip intact. It is stout, transverse dimension $=5 \mathrm{~mm}$, antero-posterior depth $=8 \mathrm{~mm}$, and in transverse section nearly flattened anteriorly, more rounded on its lateral side. The enamel band wraps onto $1 / 3$ of the lateral side, and bears no grooves or ridges, but is pigmented orange-red.

The molar from Tatrot is somewhat polished by abrasion and the enamel is pitted by exposure. It is considered to represent a right M3 due to its asymmetrical shape, and flattened anterior wall, although the single interdental appression facet is nearly unrecognizable. Its numerous transverse enamel lakes represent the traces of major transverse lophs, with spurs between them, subdividing the lakes. Atypical for a right $M 3$, as here interpreted, a lingual lake is elongated posterobuccally, rather than anterobuccally. Remnants of two small buccal roots are evident; a large lingual root extends posteriorly to support the medial side and back of the tooth. Dimensions are $10.2 \mathrm{~mm}$ long, $10.1 \mathrm{~mm}$ wide.

Discussion. These fossils do not include material definitive at the species level, and identification as Hystrix is based on the multiple enamel loops in the molar and on large size similar to porcupines previously found in the late Miocene of Pakistan. Careful analysis by Van Weers and Rook (2003) showed that known Siwalik fossils of Miocene age are not distinguishable from Hystrix primigenia. The incisor from Bhandar likely represents this species, but the Pliocene molar is considerably younger and conceivably represents a distinct species. Its dimensions are close to but above the size range cited by Van Weers and Rook (2003) for Hystrix primigenia. 
Order Lagomorpha Brandt, 1855

Family Leporidae Fischer, 1817

Genus Alilepus Dice, 1931

Type species. A. annectens (Schlosser, 1924) from the late Miocene locality, Ertemte, Inner Mongolia.

Alilepus elongatus Winkler et al., 2011

(Fig. 5a, b)

Studied material. PUPC 09/33, right dentary fragment with alveolus for p3, damaged p4 and m1, and alveolus for anterior root of $\mathrm{m} 2$ from $\mathrm{H} 18,6.6$ to $6.7 \mathrm{Ma}$.

Description. The jaw fragment represents a large rabbit, the size of described Alilepus elongatus.

Preserved dentary depth below p4 is $11 \mathrm{~mm}$. Although not well preserved, it has matrix filling the alveolus for $\mathrm{p} 3$, which indicates a length of $\sim 4.4 \mathrm{~mm}$ and width of $3.7 \mathrm{~mm}$ for the anterior premolar. Dimensions of $\mathrm{p} 4$ are $2.8 \mathrm{~mm}$ long by $3.3 \mathrm{~mm}$ maximum width; and of $\mathrm{m} 1,2.7$ by 3.45 $\mathrm{mm}$. Enamel of the cheek teeth is heaviest buccally and on the distal wall of the trigonid, and in occlusal view the enamel trace undulates only slightly.

Discussion. The rabbit is identified based on occurrence in the area of a single kind of leporid in strata of similar age. The cheek tooth dimensions for PUPC 09/33 are consistent with the species as published by Winkler et al. (2011), except that the p3 seems large, due likely to an overestimate, since length and width are estimated only from the alveolus. Although poorly preserved, the specimen provides an approximate jaw depth, not previously known. It complements the fossils reported by Winkler et al. (2011), which date to about 7 to $7.4 \mathrm{Ma}$; 
isolated teeth in that study date to about 6.5 Ma. Alilepus is a late Miocene immigrant into the Indian subcontinent.

\section{Discussion}

The fossils reported here are important because they add size and morphological data to assess variation in poorly known species, and because they extend or fill in the known time ranges for these species. The bamboo rat represented by PUPC 00/37 is comparable morphologically to the holotype of Miorhizomys choristos (Flynn 1982), but is a bit larger. Its deep dentary and chisellike incisor are typical of fossorial crown bamboo rats, Tribe Rhizomyini. Its distinctive molar morphology with isolated entoconids, weak longitudinal connections, and diminutive posterior enamel lake on $\mathrm{m} 3$ match the holotype and other specimens attributed to the species, including material from Haritalyangar, India (Flynn et al. 1990; Table 1 here). Several previously known M. choristos jaws from the Potwar Plateau date to 8.4-8.3 Ma, and the Haritalyangar material is perhaps somewhat older (Pillans et al. 2005). One fragmentary specimen found in the Hasnot area (YGSP 37068) in recent years dates to about $7 \mathrm{Ma}$. The new Bhandar specimen, in good condition, is the youngest known M. choristos (Fig. 6).

The remaining rhizomyine dentaries share features that are primitive with respect to Rhizomyini and are classified as Tachyoryctinae. Most striking are the shallower dentary with relatively heavier muscle scar of the lower masseteric crest. The lower crest meets the upper crest slightly more posteriorly than in Miorhizomys, but then continues with an anterior extension below m1. The incisor is quite different: round with median longitudinal ridge. The incisor does not show the heavy, chisel morphology of tooth-diggers. The molars are less derived than those of 
Rhizomyini; they are more elongated with complete transverse lophs, longitudinal crests, and less reduced $\mathrm{m} 3$.

New hemi-mandibles with dentition nicely complement what is known of Rhizomyides sivalensis. The new fossils, representing young and old individuals complement the large dental variation and size range (Table 1) for Rhizomyides sivalensis. The dentary is thickened laterally at the lower masseteric crest, and the lower incisor invariably is strongly rounded with a single persistent median ridge on the enamel. Molars appear to change in dimensions with wear, and the ontogeny is captured by comparing specimens in early and late wear. The worn (occlusal) surface increases in width with wear, and decreases in length, although length shortening is countered in $\mathrm{m} 3$ by the fact that its distal wall extends posteriorly toward the root. Rhizomyides has stronger, more independent mesolophids than Miorhizomys, and less inflated cusps. The entoconids are smaller and merged into hypolophids, and longitudinal crests continue into late wear. Left and right dentitions of the same individual differ somewhat.

Early workers recorded Rhizomyides sivalensis at Haritalyangar, India, and the Hasnot region, Pakistan (Lydekker 1878, Black 1972). Jacobs (1978) recovered specimens in the Hasnot region which proved to be assignable to this species. Rhizomyides sivalensis occurs in the Dhok Pathan Formation of the Potwar Plateau, Pakistan, in rocks spanning 7.3 to 6.5 Ma. The new Bhandar specimens fall at the young end of that time range. The specimen of Protachyoryctes tatroti reported here comes from near the type area for the species and is younger than specimens with good provenance (Fig. 6).

Hystrix has been known from the late Miocene Siwaliks for well over a century, beginning when Lydekker $(1878,1884)$ named and described a jaw from the Hasnot region Hystrix sivalensis. 
Currently, based on the comprehensive work of van Weers (e.g., van Weers and Rook, 2003), the Miocene Siwalik porcupine is considered indistinguishable from the western contemporaneous member of the Pikermian chronofauna, Hystrix primigenia. Barry et al. (2002) note the late Miocene introduction of this large rodent into the Siwalik fauna at about $8 \mathrm{Ma}$. Hystrix appears to have remained an element of the South Asian mammal fauna to the present. We document the genus in the late Pliocene at the classical Tatrot site, overlying the Dhok Pathan Formation. Being large and significantly younger than known late Miocene porcupines, it possibly represents another species of the genus.

Every specimen of Alilepus elongatus is important as it is a poorly-represented immigrant to the Indian subcontinent in the late Miocene, arriving before 7.4 Ma (Barry et al. 2002). The new Bhandar specimen is the only known partial mandible. This record is younger than the type material of the species.

\section{Conclusion}

New surface finds of fossil jaws and teeth from the Hasnot region of the Potwar Plateau, Pakistan, add morphological and biostratigraphic data for known late Miocene Siwalik small mammal species ranges (Fig. 6). The several Miocene age rhizomyines include a member of the crown bamboo rats, Tribe Rhizomyini (Miorhizomys choristos), and two tachyoryctin genera, Rhizomyides and Protachyoryctes. In addition to the rhizomyine species, the new material represents porcupines (Hystrix) and the leporid Alilepus elongatus, both late Miocene immigrants to the Indian Subcontinent. The new occurrences are plotted with previously well-documented occurrences to update the biostratigraphic ranges of these species. The newly recovered 
specimens point to the importance of continued collecting in the Siwalik deposits of the Indian Subcontinent combined with careful preservation of geological provenance data.

Acknowledgments We thank the government of Pakistan and University of the Punjab authorities for supporting this research. Prof. Dr. Muhammad Akhtar and Syed Ghyour Abbas are thanked for their help in the field. Mr. Adeeb Babar prepared Figure 1. Dr. John C. Barry kindly advised us on age assessment of the strata of the Hasnot area. Irina Ruf made many helpful suggestions, and we thank Lutz Maul (and anonymous) for careful reading that led to an improved manuscript.

\section{References}

Barry, J.C., M.E. Morgan, L.J. Flynn, D. Pilbeam, A.K. Behrensmeyer, S. Mahmood Raza, I.A. Khan, C. Badgley, J. Hicks, and J. Kelley. 2002. Faunal and environmental change in the Late Miocene Siwaliks of Northern Pakistan. Paleobiology Memoir 3: 1-71.

Black, C.C. 1972. Review of fossil rodents from the Neogene Siwalik Beds of India and Pakistan. Palaeonotology 15(2): 238-266.

Bohlin, B. 1946. The fossil mammals from the Tertiary deposit of Taben-buluk, western Kansu. Part II: Simplicidentata, Carnivora, Artiodactyla, Perissodactyla, and Primates. Sino-Swedish Expedition Publication 28, 6 (4): 1-259, 9 pls.

Bowdich, T.E. 1821. An analysis of the natural classifications of Mammalia, for the use of students and travelers. Paris: J. Smith. 
Brandt, J.F. 1855. Beitrage zur nähern Kenntniss der Säugethiere Russland's. Kaiserlichen Akademie der Wissensfchaften, Saint Petersburg, Mémoires Mathématiques, Physiques et Naturelles 7: 1-365.

Brown, B., W.K. Gregory, and M. Hellman. 1924. On three incomplete anthropoid jaws from the Siwaliks, India. American Museum Novitates 130: 1-9.

Dice, L.R. 1931. Alilepus, a new name to replace Allolagus Dice, preoccupied, and notes on several species of fossil hares. Journal of Mammalogy, 12:159-160.

Fischer von Waldheim, G. 1817. Adversaria zoologica. Mémoires de la Société Impériale des Naturalistes de Moscou. 5 : 368-428.

Flynn, L.J. 1982. Systematic revision of Siwalik Rhizomyidae (Rodentia). Géobios 15: 327-389. Flynn, L.J. 2009. The antiquity of Rhizomys and independent acquisition of fossorial traits in subterranean muroids. In Systematic Mammalogy: Contributions in Honor of Guy G. Musser, eds. R.S. Voss and M.D. Carleton, 128-156. New York: Bulletin of the American Museum of Natural History 331.

Flynn, L.J., A. Sahni, J.J. Jaeger, B. Singh, S.B. Bhatia. 1990. Additional fossil rodents from the Siwalik Beds of India. Proceedings of the Koninklijke Nederlandse Akademie van Wentenschappen B 93 (1): 7-20.

Gray, J.E. 1821. On the natural arrangement of vertebrose animals. London Medical Repository 15: 296-310.

Hinton, M.A.C. 1933. Diagnoses of new genera and species of rodents from Indian Tertiary deposits. Annals and Magazine of Natural History Series 10, 12: 620-622. 
Jacobs, L.L. 1978. Fossil rodents (Rhizomyidae \& Muridae) from Neogene Siwalik deposits, Pakistan. Museum of Northern Arizona Press Bulletin 52: 1-103.

Lewis, G. E. 1937. A new Siwalik correlation. American Journal of Science (Series 5) 33: 191-204.

Linnaeus, C. 1758. Systema naturae per regna tria naturae, Secundum Classes, Ordines, Genera, Species cum characteribus, differentiis, synonymis, locis. Vol. 1, Regnuma Animale, $10^{\text {th }}$ ed. Stockholm: Laurentii Salvi.

Lydekker, R. 1878. Notices of Siwalik mammals. Records of the Geological Survey of India 11: 64104.

Lydekker, R. 1884. Indian Tertiary and post-Tertiary Vertebrata. Part 3. Rodents and new ruminants from the Siwaliks and synopsis of Mammalia. Memoirs of the Geological Survey of India 10(3): 105-134.

Pillans, B., M. Williams, D. Cameron, R. Patnaik, J. Hogarth, A. Sahni, J.C. Sharma, F. Williams, and R.L. Bernor. 2005. Revised correlation of the Haritalyangar magnetostrtigraphy, Indian Siwaliks: implications for the age of the Miocene hominids Indopithecus and Sivapithecus, with a note on a new hominid tooth. Journal of Human Evolution 48: 507-515.

Van Weers, D.J., and L. Rook. 2003. Turolian and Ruscinian porcupines (genus Hystrix, Rodentia) from Europe, Asia, and North Africa. Paläontologische Zeitschrift 77(1): 95-113.

Winge, H. 1887. Jordfundne og nulevende Gnavere (Rodentia) fra Lagoa Santa, Minas Geraes, Brasilien. E Museo Lundii, University of Copenhagen 1: 1-178.

Winkler, A.J., L.J. Flynn, and Y. Tomida. 2011. Fossil lagomorphs from the Potwar Plateau, northern Pakistan. Palaeontologia Electronica 14.3.38A, 16 p., http:palaeoelectronica.org/toc.htm. 


\section{FIGURE CAPTIONS}

Figure 1. Map showing overview of much of the Indian Subcontinent and outcrop area of the Siwalik Group formations, inset showing the Punjab province, which includes the Potwar Plateau, and close-up of the Hasnot area. The principal fossil localities are H16 and H18, very near Bhandar Village.

Figure 2. Cross sections of lower incisors of Rhizomyinae. Left, the tachyoryctin Rhizomyides sivalensis, showing the less derived rounded enamel with characteristic ridge (arrow), and the bamboo rat Miorhizomys choristos (Tribe Rhizomyini, right), showing the features of large size, long A-P dimension, and flattened enamel surface. Anterior views of PUPC 09/30, R. sivalensis right incisor, and PUPC 0-0/37, M. choristos left incisor drawn to the same scale.

Figure 3. PUPC 00/37, Miorhizomys choristos left jaw (a-c), and PUPC 09/30, adult Rhizomyides sivalensis right jaw with worn m2-3 (d-f). Lateral views of the dentaries $(b, e)$ show the difference in jaw depth, and the views of $R$. sivalensis $(\mathrm{d}, \mathrm{e})$ show the inflated lower masseteric crest.

Figure 4. PUPC 09/31 sand 09/32, left $(a, d, f)$ and right $(b, e)$ dentaries of the same individual of Rhizomyides sivalensis; these are paired in anatomical position (c) with $5 \mathrm{~mm}$ scale. Occlusal, lateral and medial views of the left dentary are stacked for viewing and posed next to occlusal and lateral views of the right dentary. Lateral and occlusal views $(g, h)$ of the smaller PUPC 90/34, right dentary fragment of Protachyoryctes tatroti, $5 \mathrm{~mm}$ scale. P. tatroti has a shallow dentary as does $R$. sivalensis.

Figure 5. Alilepus elongatus, PUPC 09/33, right jaw fragment with $\mathrm{p} 4 \mathrm{~m} 1$ in occlusal and lateral view (a, b), anterior to right. Hystrix sp. (c-e): occlusal and lingual views of PUPC 09/35, right M3 (c, d); (e) is an isolated left upper incisor in apical, medial, lateral, labial views (left to right). 
Figure 6. Biostratigraphic ranges in the Potwar Plateau of taxa studied here. On the left is the time scale based on magnetostratigraphy updated from Barry et al. (2002), with ages in millions of years. To the right of the time line are locality numbers. Vertical lines show the ranges of five species, circles show dated localities: filled circles are Y-GSP localities and open circles represent the new Bhandar sites. We interpret oldest sites as first occurrences of taxa. The genus Hystrix is known to persist into the Pliocene, but there is no indication that any of the species became extinct by the end of the Miocene. 


$$
0
$$



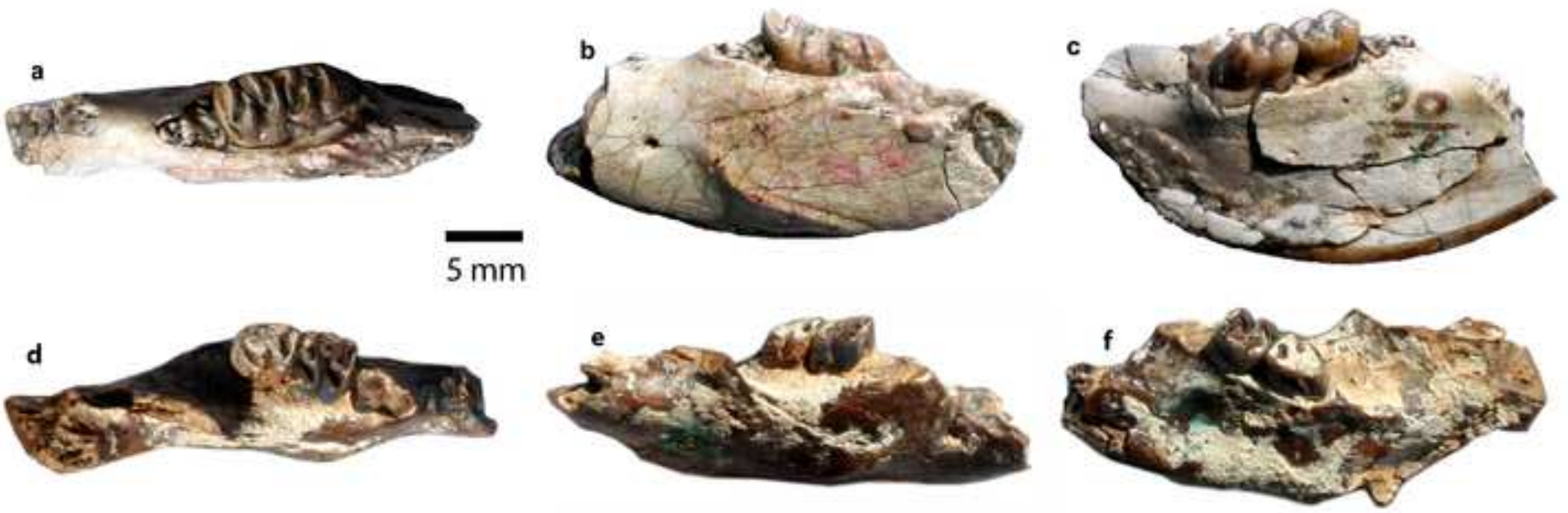

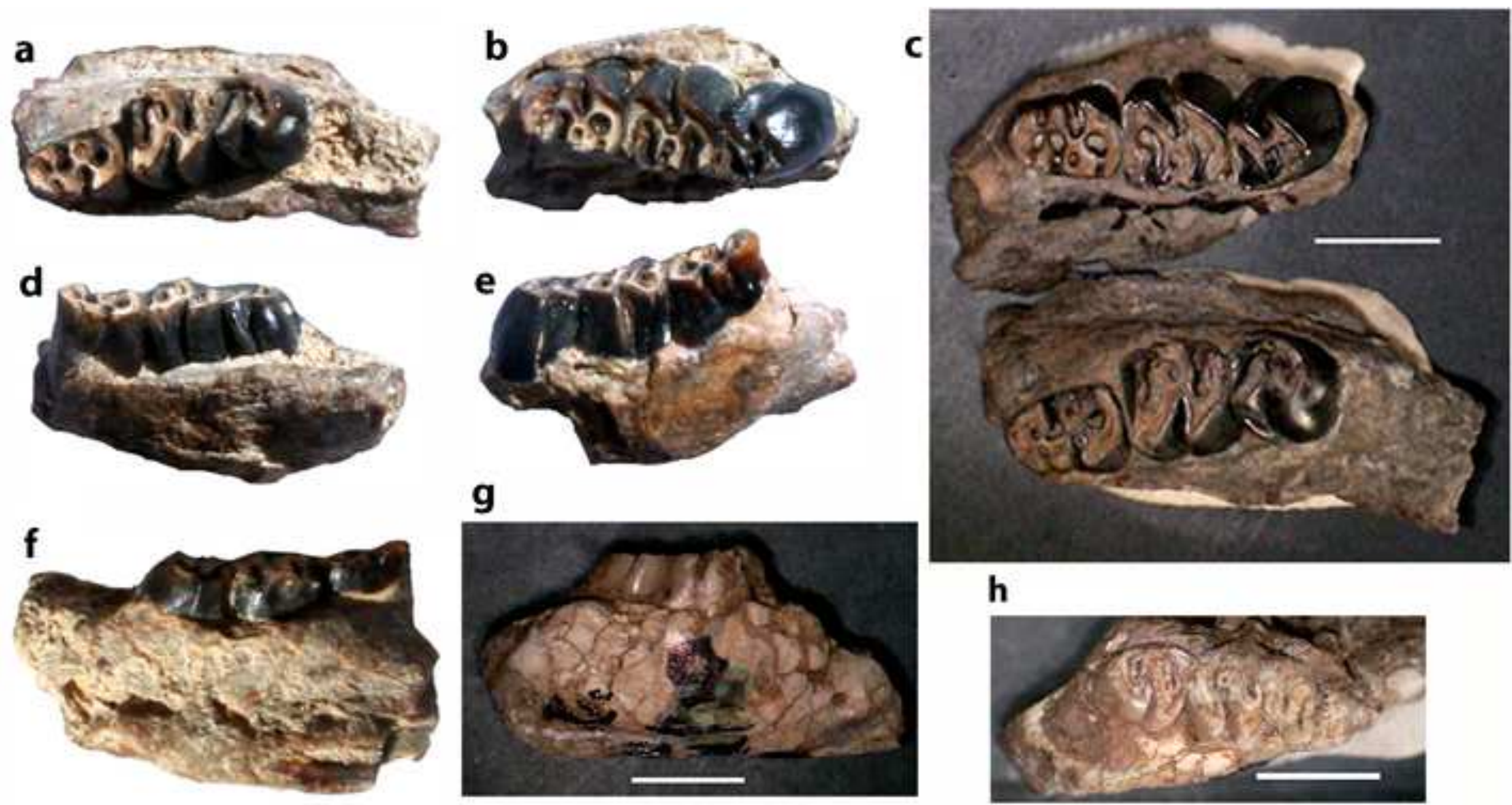

h

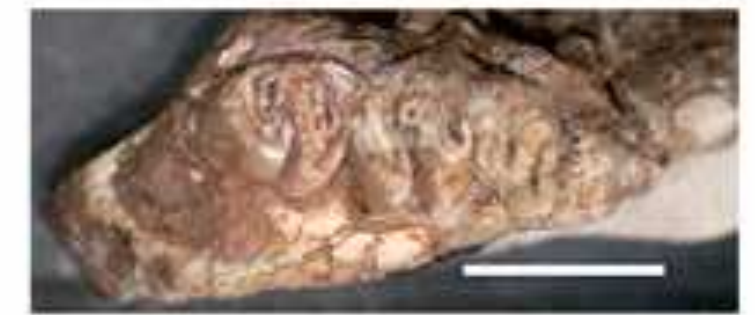




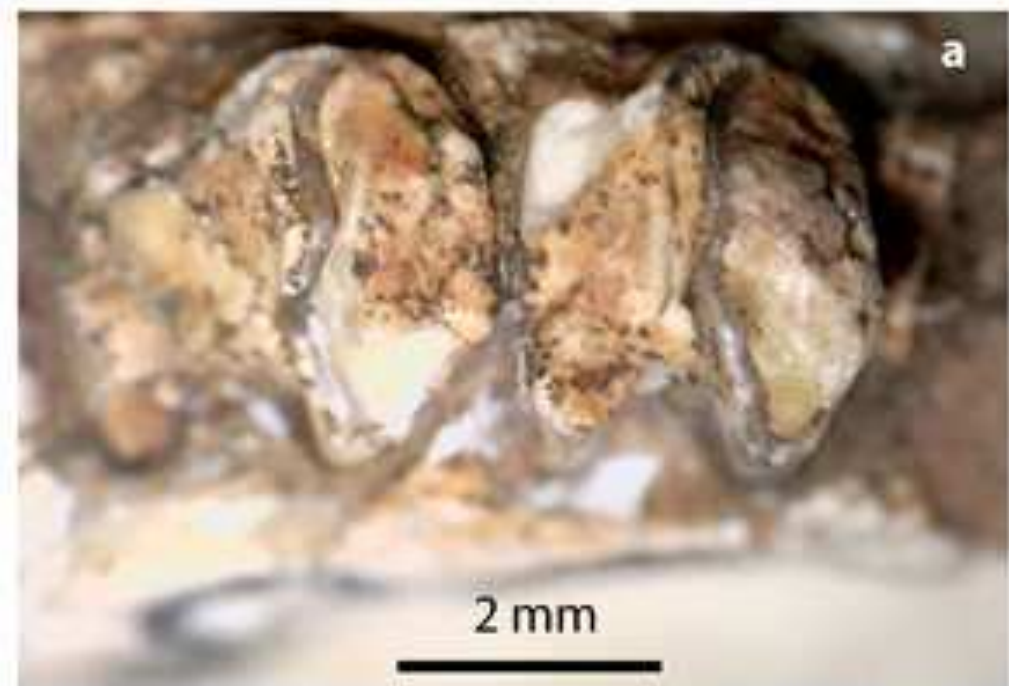

b
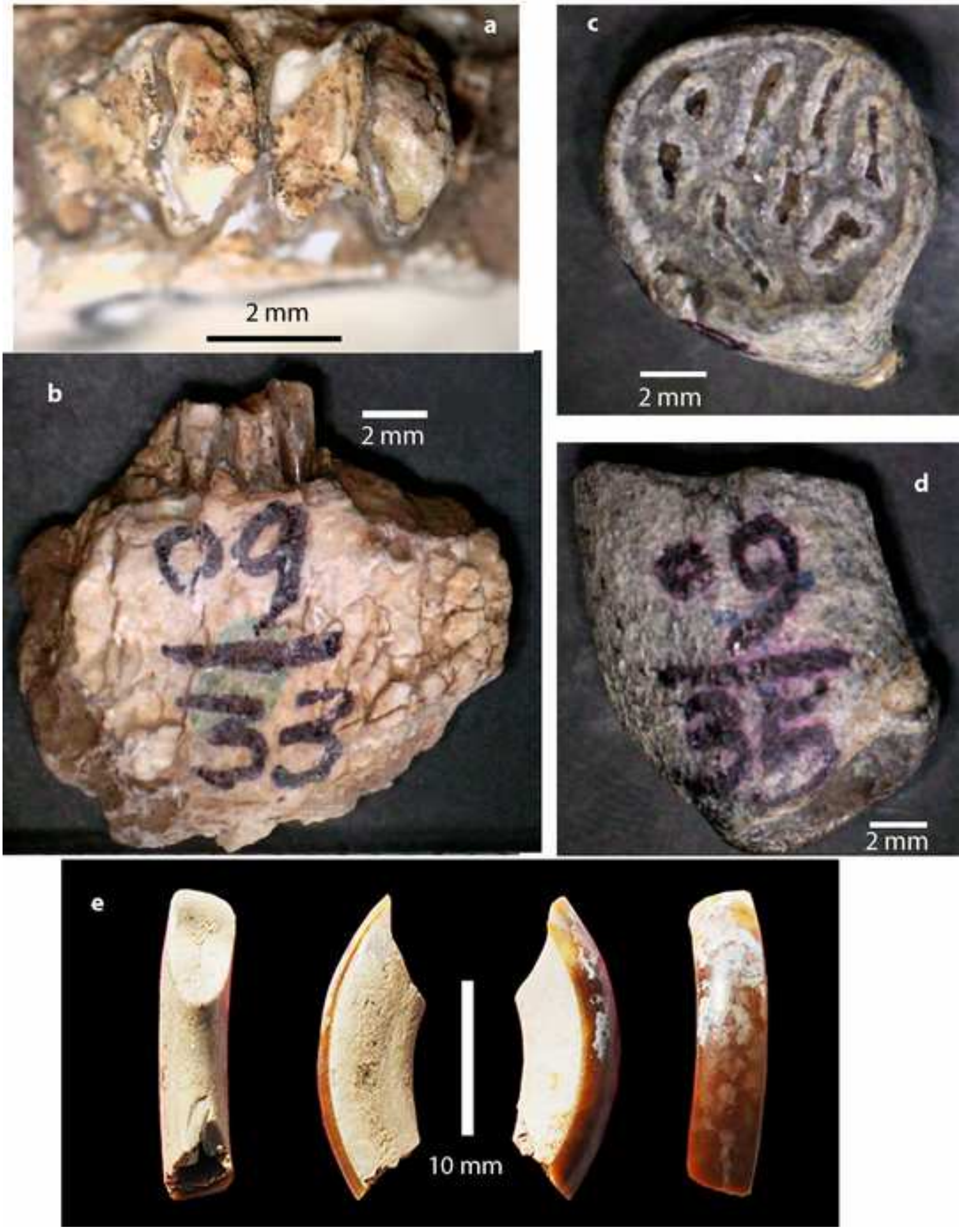
Table 1. Dimensions (molar rows and teeth) for Miorhizomys choristos and Protachyoryctes tatroti specimens compared with Rhizomyides sivalensis. *: row length based on alveoli

\begin{tabular}{|c|c|c|c|c|c|c|c|c|}
\hline \multicolumn{4}{|c|}{ Miorhizomys choristos } & \multicolumn{5}{|c|}{ Protachyoryctes tatroti } \\
\hline PUPC & \multicolumn{2}{|c|}{\begin{tabular}{l|l|l} 
YGSP YGSP (old) &
\end{tabular}} & VPL/BS/ & PUPC & GSI D272 & YGSP & YGSP & YGSP \\
\hline 0037 & 4053 & 16200 & PU 102 & 0934 & & 8360 & 15336 & 50949 \\
\hline $13.6 *$ & $12.5^{*}$ & $12.4 *$ & $12.1 *$ & $10.4^{*}$ & 9.9 & $11.2 *$ & 11 & 11 \\
\hline $\mathrm{x}$ & $\mathrm{x}$ & $\mathrm{x}$ & $\mathrm{x}$ & $\mathrm{X}$ & 3.56 & $\mathrm{x}$ & 3.88 & 3.8 \\
\hline $\mathrm{x}$ & 3.1 & $\mathrm{x}$ & 3 & $\mathrm{X}$ & 3.06 & 3 & 3.16 & 2.75 \\
\hline 5.05 & 5.55 & 3.9 & 4.2 & 3.35 & 3.56 & 3.63 & 3.59 & 3.6 \\
\hline 4.35 & 4.38 & 4.6 & 4.1 & 3.5 & 3.75 & 3.94 & 3.52 & 3.35 \\
\hline 5.8 & 5.22 & 4.8 & 5.2 & 4.05 & 4 & 4.28 & 3.9 & 3.1 \\
\hline 4.4 & 4.25 & 4.1 & 4.2 & 3.4 & 3.06 & 3.38 & 3.28 & 3.9 \\
\hline 6.1 & 5.2 & 6.2 & 5 & 2.9 & $\mathrm{x}$ & 2.6 & 2.8 & $\bar{x}$ \\
\hline \begin{tabular}{|l|}
4.3 \\
\end{tabular} & 4 & 3.6 & 3.2 & 2.3 & $x$ & 2.2 & 1.9 & $\bar{x}$ \\
\hline
\end{tabular}

Rhizomyides sivalensis

\begin{tabular}{|c|c|c|c|c|c|c|c|c|c|c|}
\hline & $\begin{array}{l}\text { PUPC } \\
0930\end{array}$ & $\begin{array}{l}\text { PUPC } \\
0931\end{array}$ & $\begin{array}{l}\text { PUPC } \\
0932\end{array}$ & GSI D97 & GSI D275 & GSI D276 & GSI D277 & $\begin{array}{r}\text { YGSP } \\
49876 \\
\end{array}$ & \begin{tabular}{r|} 
YGSP \\
15319 \\
\end{tabular} & $\begin{array}{r}\text { YGSP } \\
50115 \\
\end{array}$ \\
\hline Molar Row & $11.7^{*}$ & 13.7 & 13.2 & $14.4^{*}$ & 13.3* & 15.3 & 14.9 & $14.2 *$ & 14.4* & $15.5^{*}$ \\
\hline L m1 & $x$ & 4.65 & 4.6 & $x$ & $\mathrm{x}$ & 5.15 & 4.6 & $x$ & $\mathrm{x}$ & $x$ \\
\hline $\mathrm{W}$ m1 & $x$ & 3.5 & 3.45 & $x$ & $\mathrm{X}$ & 3.45 & 4.1 & $\mathrm{x}$ & 3.7 & $x$ \\
\hline L m2 & 3.75 & 4.3 & 4.35 & 4.55 & 4.55 & 5.25 & 4.05 & 4.3 & 4 & 4.7 \\
\hline $\mathrm{W}$ m2 & 4.3 & 4.5 & 4.25 & 4.8 & 4.2 & 4.31 & 4.5 & 4.2 & 4.94 & 4.6 \\
\hline L m3 & 4.45 & 4.85 & 4.6 & 5.9 & 5.8 & 5.44 & 5.5 & 4.75 & 5.38 & $x$ \\
\hline $\mathrm{W}$ m3 & 3.85 & 4.25 & 4.2 & 4.2 & 4.2 & 4.31 & 3.6 & 3.8 & 4.63 & $\bar{x}$ \\
\hline A-P incisor & 3.85 & 3.25 & 3.2 & 3.95 & $x$ & $\mathrm{x}$ & 3.55 & 3.45 & 3.94 & 3.9 \\
\hline W incisor & 2.85 & 2.5 & 2.55 & 3.05 & $\mathrm{x}$ & $x$ & 3.15 & 2.7 & 3.44 & 2.95 \\
\hline
\end{tabular}




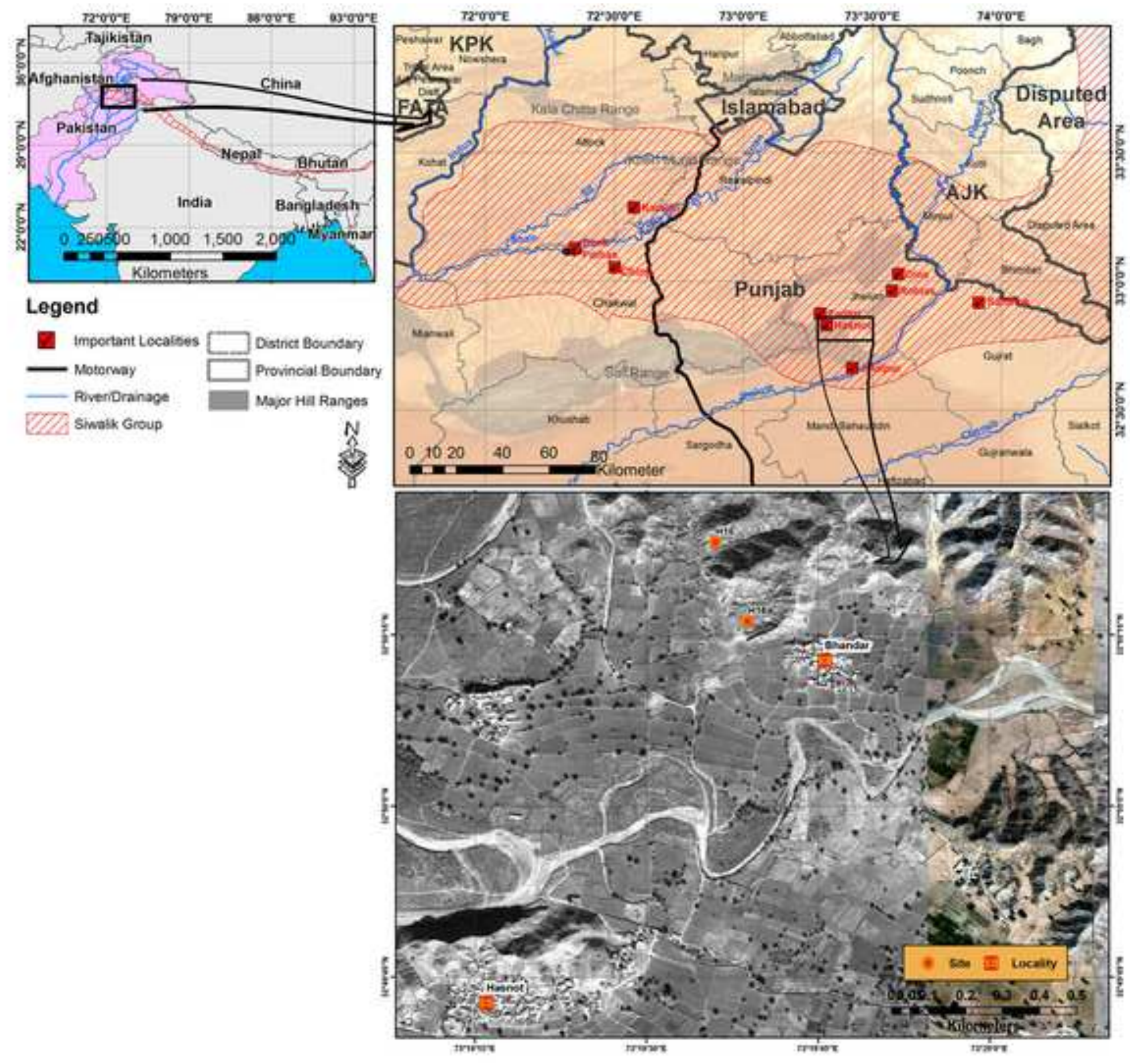

